\title{
İç Anadolu Bölgesi Ağızlarında Geçen İkilemeler Üzerine Bir Değerlendirme
}

Serdar YAVUZ*

Burak TELLI' ${ }^{* *}$

\section{Özet}

Dilimizin zengin söz varlığı içerisinde yer alan ikilemeler, genellikle anlamı pekiştirmek, güçlendirmek için oluşturulmuş sözcük grupları olarak tanımlanır. Başlı başına yeni bir kelime türetme yolu olarak da değerlendirilen bu sözcük gruplarını özellikle yapılışları ve cümle içindeki görevleri yönünden üzerinde çalışılması gereken bir konu olduğunu düşünmekteyiz. Ayrıca metinlerde geçen ikileme örneklerinin ait olduğu dilin söz varlığına da katkısı tartışılmazdır. Bu düşünceden yola çıkarak çalışmamızda İ ç Anadolu Bölgesi'nde yer alan 13 ile ait derlenmiş ağız metinlerini tarayarak bölge ağızlarında geçen ikilemeleri tespit ettik. Öncelikle ikilemenin tanımı üzerinde durduk. Bugüne kadar yapılan çalışmalardan ikilemeyle ilgili literatür taraması yaparak ikilemenin tanımı ve özellikleri üzerinde ayrıntılı bir şekilde durmaya çalıştık. Konuyla ilgili yapılmış diğer çalışmalarda ikileme yerine kullanılan tekrarlar, yinelemeler, ikizleme gibi faklı terimlerin varlığından söz ettik. Sonrasında metinlerden tespit ettiğimiz tüm ikilemeleri illere göre sıraladık ve bu örnekleri yapılışlarına ve sözcük türlerine göre iki ana başlık altında değerlendirdik. Alt başlıklar oluşturarak da metinlerde geçen ikileme örneklerinin tüm farklı görev ve yapılış şekillerini açıklamaya çalıştık. Değerlendirmemizi yaparken öncelikle başlığın genel açıklamasını yaptık ve devamında bölge ağızlarına ait metinlerden tespit ettiğimiz o başlıkla ilgili ikilemelerden örnekler verdik. Metinlerin taramasını yaparken belirlediğimiz tüm ikilemeleri yazı dilimizde olup olmadığı ayrımını yapmadan fişlendirdik. Tüm ikilemeleri ortaya çıkardığımızda yazı dilimizde olmayan bazı ikilemelerin İç Anadolu ağızlarında yaşadığını gördük. Çalışmamızın bu yönüyle de Türkoloji alanına ayrı bir katkı sağlayacağı düşüncesindeyiz.

Anahtar Kelimeler: İkileme, tekrarlar, İç Anadolu, ağız, Türkçe.

\footnotetext{
"Yrd. Doç. Dr., Adıyaman Üniversitesi Fen-Edebiyat Fakültesi Türk Dili ve Edebiyatı Bölümü Yeni Türk Dili Bilim Dalı Öğretim Üyesi, srdryavuz23@gmail.com ** Doktora Öğrencisi, Adıyaman Üniversitesi Fen-Edebiyat Fakültesi Türk Dili ve Edebiyatı Bölümü Yeni Türk Dili Bilim Dalı btelli46@gmail.com
} 


\title{
An Evaluation Research On Reduplications Aforesaid İn Central Anatolian Region Dialects
}

\begin{abstract}
Reduplications, taking place in our tongue's rich vocabulary are usually defined as phrases created for reinforcement and strengthen the meaning. We consider these phrases, which is also seen as a new word formation method in itself, as a worth stressing subject especially on formation and intra sentence functions. Furthermore, it is out of debate that reduplication examples mentioned in texts contribute to the tongue's vocabulary. With this in mind, in our study with scanning compiled dialect texts belonging to 13 provinces of Central Anatolian Region we ascertained reduplications mentioned in regions dialects. First of all, we emphasized on the definition of reduplication. We tried to emphasize on the definition and functions of reduplication in detail by reviewing the literature of the ever made studies related to the subject. We mentioned about the entity of repetitions, reiterations, and doublings which were used as substitutes in other related studies. Later on, we arranged the reduplications that we ascertained before according to the provinces and analyzed these examples under two main topics; formation and word class. With sub-headings, we tried to explain all the different functions and formations manners of the reduplications mentioned in the texts. While analyzing, we begin with the common explanation of the heading, and then give reduplication examples that were previously ascertained from the region dialects, related with the heading. All the reduplications found during text scanning, regardless of existence in written language, are made card index. When all the reduplications were revealed, it is seen that some of the reduplications which were not present in our written language continued its existence in Central Anatolian dialects. On that sense we are of the opinion that this study will contribute to the field of Turcology from a different point.
\end{abstract}

Key Words: reduplication, repetitions, Central Anatolia, dialect, Turkish

\section{Giriş}

Türkçenin zengin söz varlığı içinde yer alan ikileme, anlatım gücünü artırmak, anlamı pekiştirmek, kavramı zenginleştirmek amacıyla, aynı sözcügün tekrar edilmesi veya anlamları birbirine yakın yahut karşıt olan ya 
da sesleri birbirini andıran iki sözcüğün yan yana kullanılmasıdır ${ }^{1}$. Türkçenin her döneminde, ifadeye ahenk kazandırmak, anlamı güçlendirmek, ifadede verilmek isteneni daha etkili bir şekilde anlatabilmek için ikilemelerden yararlanılmıştır.

Diğer dillerde farklı terimlerle ifade edilen ikileme; İngilizcede hendiadyoin, Almancada hendiadyoin, verdoppelung, zwillingsformen Fransizcada hendiodyoin ve redoublement, Osmanlicada terkib-i ihtimali, atftefsiri, mühmelat terimleriyle karşılanır².

İkileme için çeşitli çalışmalarda benzer terimler kullanılmıştır. Ergin ${ }^{3}$, Gülensoy ${ }^{4}$ ve Tuna ${ }^{5}$ ikileme için "tekrarlar", Karaağaç ${ }^{6}$ "yinelemeler", Bilgegil7 "ikizleme", Karahan ${ }^{8}$ "tekrar grubu", Korkmaz ${ }^{9}$ ve Hatiboğlu ${ }^{10}$ "ikilemeler", Ağakay ve Gencan da "ikizlemeler"11 terimini kullanmışlardır.

Dilbilgisi kitaplarında ve çeşitli kaynaklarda araştırmacılar ikilemeyi çeşitli şekillerde tarif etmişlerdir:

Muharrem Ergin, Türk Dil Bilgisi kitabında tekrarlar terimini kullandıkları ikileme için "Tekrarlar aynı cinsten iki kelimenin arka arkaya getirilmesi ile meydana gelen kelime gruplarıdır." tanımını yapmıştır.

Leyla Karahan, Türkçede Söz Dizimi eserinde bu tekrar grubunu "Bir nesneyi, bir niteliği, bir hareketi karşılamak üzere eş görevli iki kelimenin meydana getirdiği kelime grubu" olarak tarif etmiştir.

M. Kaya Bilgegil, Türkçe Dilbilgisi'nde ikilemeyi ikizleme olarak adlandırıp "Araya hiçbir ek girmeksizin aynı cinsten iki kelimenin tekrarıyla hasıl olan gruplar" şeklinde tanımlamıştır.

\footnotetext{
${ }^{1}$ Vecihe Hatiboğlu, Türk Dilinde İkileme, s. 9, Ankara Üniversitesi Basımevi, Ankara 1981.

${ }^{2}$ Age, s. 9.

${ }^{3}$ Muharrem Ergin, Türk Dil Bilgisi, s. 377, Bayrak Yay., İstanbul 2012.

${ }^{4}$ Tuncer Gülensoy, Türkçe El Kitabı, s. 617, Akçağ Yay., Ankara 2010.

${ }^{5}$ Osman Nedim Tuna, Türkçede Tekrarlar, TDED, Cilt 3, S: 2-3, 1949, s. 429-447.

${ }^{6}$ Günay Karaağaç, Türkçe Dil Bilgisi, s. 476, Akçağ Yay., Ankara 2012.

${ }^{7}$ Kaya Bilgegil, Türkçe Dilbilgisi, s. 161, Salkımsöğüt yay., Erzurum 2009.

${ }^{8}$ Leyla Karahan, Türkçede Söz Dizimi, s. 60, Akçă̆ Yay., Ankara 2012.

${ }_{9}^{9}$ Zeynep Korkmaz, Gramer Terimleri Sözlüğü, s. 123, TDK Yay., Ankara 2010.

${ }^{10}$ Vecihe Hatiboğlu, age, s. 9.

11 Tahsin Aktaş, "Yapı ve Anlam Bakımından Almanca ve Türkçede İkilemeler”, s.

565, Türk Dili Dergisi, S: 539, 1996, s. 565-575.
} 
Zeynep Korkmaz, Gramer Terimleri Sözlüğ̈̈'nde "Aralarında belli bir ses düzeni bulunan, biçim ve anlamca birbiriyle ilişkili olan, aynı, yakın ya da zıt anlamlı iki veya daha çok kelimenin bir tek kelime gibi anlam göstermek üzere yan yana gelmesi ile oluşturulan kelime grubu" şeklinde ikilemenin tanımını yapmiştır.

Günay Karaağaç, ayrıntılı gramer kitabı Türkçenin Dil Bilgisi'nde, yineleme öbeği adını verdiği ikilemeleri "Bir varlığı veya bir eylemi karşılamak üzere eş görevli iki sözün oluşturduğu söz öbeğì" olarak açılamıştır.

Hamza Zülfikar, Türkçede Ses Yansımalı Kelimeler eserinde, "Başlıca amacı anlamı pekiştirme, güçlü kılma, ikizleşmelerle daha da anlamı kuvvetlendirmek olan ikilemeler, herhangi bir lenguistik birimin tekrarıdır." diyerek ikilemeyi tarif etmiştir.

Osman Nedim Tuna, Türkçede Tekrarlar isimli makalesinde "Sözlerin belli kurallara bağlı olarak yan yana kullanılması"; Üstünova ise Dede Korkut Destanlarında Aralıkl İkilemeler makalesinde ikilemeyi "Ses, hece, sözcük, sözcük öbeği, cümle tekrarına dayalı dil düzenlemeleri" şeklinde tanımlamışlardır.

Türkçe Sözlük ise ikilemeyi "Anlamı güçlendirmek için ayn kelimenin tekrarlanması, anlamları birbirine yakın, karşıt olan veya sesleri birbirini andıran kelimelerin yan yana kullanılması" olarak tarif etmiştir ${ }^{12}$.

Görüldüğü gibi ikilemeyle ilgili yapılan tanımlarda en kapsamlı tanım Vecihe Hatipoğlu'na sonra da Zeynep Korkmaz'a aittir. Her ikisi de diğer araştırmacılardan farklı olarak ikilemenin sahip olduğu ses düzeninden bahsetmiştir. Bu ses düzeni ikilemeye ritmik bir söyleyiş kazandırmıştır ve bu ritmik söyleyiş ikilemenin önemli bir özelliği olmuştur. Bu yüzdendir ki ardı ardına sıralanmış ya da çeşitli şekillerde tekrar edilmiş her sözcük grubuna ikileme demek doğru olmayacağı gibi ikileme ile tekrar grubunu aynı kavram olarak değerlendirmek de doğru bir yaklaşım olmayacaktır. Tanımı noktasında çok farklılık göstermeyen ikileme, terim olarak isimlendirilirken ise bu birlik pek sağlanamamıştır.

İkilemelerle ilgili yapılmış en kapsamlı çalışma olan Vecihe Hatiboğlu'nun Türk Dilinde İkileme isimli eserinde ${ }^{13}$, ikilemenin Türkçenin bilinenden çok daha önemli bir özelliği olduğundan, ünlü uyumları, ünsüz benzeşmeleri gibi Türkçenin kuralları arasında yer alması gerektiğinden ve

\footnotetext{
${ }^{12}$ Türkçe Sözlük, s.1165, TDK Yay., Ankara 2011.

${ }^{13}$ Vecihe Hatiboğlu, age, s.9.
} 
ikileme konusu ele alınmadan Türkçenin yapı bakımından aydınlatılamayacağından söz eder.

İkilemeler, cümle içerisinde anlamlı ve görevli sözcüklerdir. Bulundukları cümleye pekiştirme, güçlendirme, abartma, çoğaltma ve kolaylaştırma gibi anlamlar katar. Türkçenin zenginliği ikileme, aslında mevcut anlam zenginliğini ifade edebilmek için yeni kelime türetme yollarından biridir. Çünkü ikileme yapılışı itibariyle çeşitli ilgilerle iki sözcügün yan yana getirilerek yeni ifade yolları oluşturur ${ }^{14}$. Alman araştırmacı Fleischer de, Wortbuilding der deutchen Gegenwartssprache isimli kitabında ikilemeyi sözcük türetmenin özel bir şekli olarak değerlendirmektedir.

Türk düşüncesindeki anlam bolluğunu kavram inceliğini karşılamak üzere, sözcük kurar gibi, türlü yönlerden birbiriyle ilgili iki sözcük yan yana getirilir ve yeni bir anlatım yolu yaratılır ${ }^{15}$. İkilemeyi meydana getiren unsurların, ikilemenin yapılışına göre her biri ayrı anlama sahip olsa da bu unsurlar ikileme haline geldiklerinde yepyeni bir anlam kazanabilmektedir. Yani ikileme, onu yapan unsurlardan anlam bakımından sıyrilıp yeni bir anlam teşkil etmiş kelime grubudur. Örneğin köşe bucak ikilemesini meydana getiren kelimeler ayrı anlamlara sahiptir. Köşe; iki duvarın birleştiği girintili veya çıkıntılı yer, iki sokağın veya caddenin kesiştiği yer ${ }^{16}$; bucak ise; kenar, köşe yer ${ }^{17}$ olarak tanımlanır. Bu iki kelime birlikte kullanıldığında yani köşe bucak şeklinde ikileme oluşturduğunda her yer olarak tanımlanır ${ }^{18}$ ve mecazi bir anlam kazanır.

Örnek: Benden köşe bucak kaçıyordu.

Onu köşe bucak aradım.

Verilen örneklerde ikileme her yerde(n), aramadı̆̆ım yer kalmadı anlamında kullanılarak ikilemeyi oluşturan unsurların her biri temel anlamlarından hemen hemen tamamen uzaklaşmış, birlikte ikileme şekliyle yeni bir anlam kazanmıştır.

\footnotetext{
${ }^{14}$ Age, s. 9.

${ }^{15}$ Age, s.9.

${ }^{16}$ Türkçe Sözlük, s. 1505, TDK Yay., Ankara 2011.

${ }^{17}$ Age, s. 407.

${ }_{18}$ Age, s. 1506.
} 
$\mathrm{Bu}$ konuyu bir örnekle daha zenginleştirelim. Örneğin az çok ikilemesini aynı şekilde inceleyelim. Az kelimesi nicelik, nitelik, güç, süre, sayı bakımından eksiklik ${ }^{19}$ anlamında; çok kelimesi ise sayı, nicelik, değer, güç, derece vb. bakımından büyük ve aşırı olan, az karşıt $\imath^{20}$ olarak tanımlanmaktadır. Az çok kelimeleri birlikte ikileme şekliyle bir parça $a^{21}$ anlamına gelmektedir.

İkileme dilimizin hem üslup zenginliği hem de Türkçenin yap1 bakımından temellerine kadar inen bir özelliği olduğu için başlı başına bir zenginlik ve yaratma gücüdür. Verilen örneklerde görüldüğü üzere ikileme aslında başlı başına bir yeni kelime türetme yoludur. İkilemeyi oluşturan kelimelerin müstakil anlamları ikileme meydana getirildikten sonra kaybolmakta ve ikilemenin iki unsuru birlikte yepyeni bir anlam teşkil etmektedir. Fakat ikilemenin bu özelliği aslında ikilemenin yapılış şekline göre bazen kendini göstermeyebilir. Örneğin yukarıda verdiğimiz örneklerde ikilemeyi oluşturan kelimeler, ikilemeyi oluşturduktan sonra kendi öz anlamlarından uzaklaşmaktaydı; fakat aynı sözcüğün tekrarı şeklindeki ikilemelerde bu özellik olmayabilir. Örneğin "Bahçemizde sepet sepet üzüm olurdu." cümlesinde "sepet sepet" birlikteliği cümleye çokluk, pekiştirme anlamı katarak sepetlerce üzüm anlamını kazandırmıştır. Bir tür bu birliktelikten yeni bir anlam ortaya çıkmamış sadece pekiştirme, çokluk anlamı katmıştır. Yukarıdaki diğer örnekler için söylediğimiz "ikilemeyi oluşturan kelimeler müstakil anlamlarından uzaklaşabilir ve ikileme birlikteliğinde yeni bir anlam kazanır." özelliği bu örnekte söz konusu olmamıştır.

İkileme Türkçenin ilk yazılı eserlerinden başlayarak tüm lehçelerinde var olan bir özelliktir. Dilin gerek yapı, gerek söz dizimi gerekse anlambilimi açısından en önemli öğelerinden birini oluşturur. Latin edebiyatında birkaç örnekle gösterilen ikilemelerin, dünya dillerinde çok az örneği vardır. Türkçeyle ayn dil ailesinde olan Korece ve Japoncada görülen ikilemeler, Türkçede oldukça yaygın bir kullanıma sahip bulunmakta ve güçlü bir anlatım imkanı vermektedir ${ }^{22}$. Türkçenin tüm dönemlerinde ve lehçelerinde var olan bu zenginlik Orhun Yazıtlarında ve Uygurcada çokça kullanılan bir özellik olmuştur. Hatta ilk Türk metinlerinden Orhun yazıtları ikileme ile başlamaktadır ${ }^{23}$. Eski Osmanlıca döneminde de özellikle düzyazıda mevcut ikilemelerin çoğunun ya yabancı sözcükten ya da bir Türkçe bir yabancı

\footnotetext{
${ }^{19}$ Age, s. 212.

${ }^{20}$ Age, s.559.

${ }^{21}$ Age, s. 215.

22 Doğan Aksan, Türkçenin Sözvarlığı, s. 60, Engin Yay., Ankara 1996.

${ }^{23}$ Vecihe Hatiboğlu, age, s. 61.
} 
sözcükten kurulduğu ve çok defa da araya ve bağlacı getirildiği görülmektedir ${ }^{24}$. İkilemeler üzerine çeşitli araştırmacılar tarafından yapılan çalışmalarda Göktürk yazıtlarında 1525, Uygur Türkçesinde 26226, Kutadgu Bilig'de 19727, Divanü Lugati't Türk'te $162^{28}$ ve Harezm dönemi eserleri olan Nehcü'l -Feradis, Kısasü'l-Enbiya ve Mukaddimetü'l-Edeb'de ${ }^{29}$ çok sayıda ikileme geçtiği ortaya konmuştur.

İkilemeler, çeşitli yollarla oluşturulan kelime gruplarıdır ve teşekkülleri ise genellikle şu şekillerdedir:

a) Aynı kelimenin tekrarı ile: yavaş yavaş, bardak bardak vb.

b) Zıt anlamlı kelimelerin tekrarı ile: az çok, ileri geri vb.

c) Eş anlamlı kelimelerin tekrarı ile: toz toprak, falan filan, yana yakıla vb.

d) Yakın anlamlı sözcüklerin birlikteliği ile: ses seda, doğru dürüst, sağ salim vb.

e) Yansıma sözcükler ile: şırıl şırıl, fısır fısır, pat küt vb.

f) Tek başına anlamsız iki kelimenin birlikteliği ile: ıvır zıvır, mırın kırın vb.

g) Biri anlamlı diğeri anlamsız sözcüklerin birlikteliği ile: eğri büğrü, ufak tefek vb.

h) Ses ilaveleri ile yapılanlar: yol mol, adam madam vb.

$\mathrm{Bu}$ maddeler ikilemelerin tasnifi noktasında birer yardımcı etken olmuştur. Söz konusu maddeler dışında elbette çeşitli tasnif şekilleri olmakla birlikte, sıraladığımız bu maddeler ikilemenin anlamsal yönden

\footnotetext{
${ }^{24}$ Age, s.78.

${ }^{25}$ Erhan Aydın, “Orhun Yazıtlarında Hendiadyoinler”, TD, S: 544, s.417-421.

${ }^{26}$ Saadet Çağatay, "Uygurcada Hendiadyoinler”, Türk Lehçeleri Üzerine Denemeler, Ankara Ü. DTCF Yay., Ankara 1978, s. 29-66

${ }_{27}$ Zuhal Kargı Ölmez, "Kutadgu Bilig'de ikilemeler (1)", Türk Dilleri Araştırmaları, s.7, 1997, s. 19-40; Zuhal Kargı Ölmez, “Kutadgu Bilig'de İkilemeler (2)”, Bahşı Ögdisi 60. Doğum Yılı Dolayısıyla Klaus Röhrborn Armă̆anı, Simurg Yay., Freiburg-İstanbul 1998, s. 235-260.

${ }^{28}$ Gülsel Sev, “Divanü Lugat'it Türk'te İkilemeler”, TD, S: 634 (Ekim 2004), s. 497-510.

29 Mehmet Dursun Erdem, "Harezm Türkçesinde İkilemeler ve Yinelemeler Üzerine", Bilig, s. 33, Bahar 2005, s. 189-225.
} 
tasnifini oluşturmuştur. Çeşitli çalışmalarda ikilemeler farklı şekillerde sınıflandırılmıştır. Genellikle de yukarıda sıraladığımız maddelerde olduğu gibi yapılış şekillerine göre sınıflandırılmıştır. İkilemeyle ilgili en geniş kaynak olan Vecihe Hatiboğlu'nun Türk Dilinde Ikileme eserinde ikileme, çok ayrıntılı bir şekilde sekiz ana başlık altında sınıflandırılmıştır ${ }^{30}$. Bu başlıklar:
a) Sözcük yapısı bakımından ikileme türleri
b) Aralıklı ikilemeler
c) Sözcük türü bakımından ikilemeler
d) Ad kök ve gövdelerinden türeyen ikilemeler
e) Eylem kök veya gövdelerinden türeyen ikilemeler
f) Görev bakımından ikilemeler
g) Anlam bakımından ikilemeler
h) Anlam bakımından ikilemeyi kuran sözcükler

İkilemeleri tekrar grubu içinde ele alan Leyla Karahan, ikilemenin özelliklerini şu şekilde sıralar ${ }^{31}$ :

a) Grupta yer alan kelimeler arasında hem şekil, hem de anlam ilişkisi vardır.

b) Tekrarlar, anlamı kuvvetlendirir; nesne ve harekete çokluk, süreklilik ve beraberlik anlamı kazandırır.

c) Bağlama ve çekim edatları dışında bütün kelimelerle tekrar grubu kurulabilir. Ünlemler tekrara elverişli kelimelerdir.

d) Grubu meydana getiren unsurlar çekim eki alabilir.

e) Grup içindeki kelimeler, eş görevlidir. Genellikle kelimeler arasında belirli bir ses düzeni bulunur. Bundan dolayı, tekrar gruplarının birçoğunda unsurların yeri değiştirilmez.

f) Grupta yer alan kelimelerden biri, zaman içinde isim, sıfat, zarf ve fiil görevi yapar.

${ }^{30}$ Vecihe Hatiboğlu, age., s.18-60

${ }^{31}$ Leyla Karahan, age, s. 60-62. 
g) $\mathrm{Bu}$ grupta her unsur kendi vurgusunu taşır. Kelimeler arasına virgül konmaz.

Türkçenin her döneminde var olan ve dilimizin zengin ağız sisteminin söz varlığı içerisinde de kendine yer bulan ikilemeler, sözcük bilimi ve anlam bilimi açısından Türkçenin zengin bir anlatım özelliğidir. Bu çalışmamızda da İç Anadolu bölgesi ağızlarında geçen ikilemeleri tespit etmeye çalıştık. Çalışmamızı hazırlarken bölge illeri ve o illere ait ilçe ve köylerden derlenen metinleri tarayarak bölgeye ait ağızlarda geçen ikilemelere ulaşmaya çalıştık. Çalışmamız sonucunda bölgenin 13 ilinden toplam 271 adet ikilemeye ulaştık. Tespit ettiğimiz bu ikilemeler ait olduğu il sırasına göre aşağıda sıralanmıştır:

$\begin{array}{ll}\text { Saya saya (Aks.) } & \text { Şakır şakır (Ank.) } \\ \text { Belli başlı (Ank.) } & \text { Bilal milal (Ank.) } \\ \text { Öte bete (Ank) } & \text { Görü görmez (Ank.) } \\ \text { †le †le (Ank.) } & \text { Geri geri (Ank.) } \\ \text { Ufak ufak (Ank.) } & \text { Pallā pallamaz (Ank.) } \\ \text { Goca goca (Ank.) } & \text { Baldur buldur (Ank.) } \\ \text { Cırlē cırlē (Ank.) } & \text { Pır pır (Ank.) } \\ \text { Düğün müğün (Ank.) } & \text { Bükrüm bükrüm (Ank.) } \\ \text { Gavga çekiş (Ank.) } & \text { Gabā gabā (Ank.) } \\ \text { Sara sara (Ank.) } & \text { Çanā çolmē (Esk.) } \\ \text { Elemeden } & \text { Türlü türlü (Esk.) } \\ \text { Çirpinduk mirpinduk (Ank.) } & \text { El ele (Esk.) } \\ \text { Dũme mũme (Ank.) } & \text { Günbür günbür (Esk.) } \\ \text { Çıkın mıkın (Ank.) } & \text { Büküle büküle (Esk.) } \\ \text { Unu munu (Ank.) } & \text { Pul pul (Esk.) } \\ \text { †le mũile (Ank.) } & \text { Teker teker (Esk.) } \\ \text { Su mu (Ank.) } & \text { Yamrı yumrular (Esk.) } \\ \text { Parsē parsē (Ank.) } & \text { Gẹce gündüz (Esk.) } \\ \end{array}$




\begin{tabular}{|c|c|}
\hline Yeşil meşil (Esk.) & Hẹlisa hẹlisa (Çank.) \\
\hline Gider gider (Esk.) & Ġule ġule (Çank.) \\
\hline Oḳlu yaylı (Esk.) & Sāline sāline (Çank.) \\
\hline Meleye meleye (Esk.) & Yisem yisem (Çank.) \\
\hline Güddüm güddüm (Esk.) & Gatı gatı (Çank.) \\
\hline Çırt bırt (Esk.) & Çıtır pıtır (Çank.) \\
\hline Dizin dizin (Esk.) & Hisım ahraba (Kar.) \\
\hline Bür bür (Esk.) & Gonu gomşu (Kar.) \\
\hline Gol gol (Esk.) & İşi gücü (Kar.) \\
\hline Bölük bölük (Esk.) & Mahalle mahalle (Kar.) \\
\hline Ĥarıl Ĥarıl (Esk.) & Böyle böyle (Kar.) \\
\hline Tihır mıhur (Çank.) & Hemen emen (Kar.) \\
\hline Çı̂ha çîha (Çank.) & Gol gola (Kar.) \\
\hline Desde desde (Çank.) & İnce ince (Kar.) \\
\hline Giş giş (Çank.) & Fakire fukāreye (Kar.) \\
\hline Civür civür (Çank.) & Böcü börtü (Kar.) \\
\hline Saf saf (Çank.) & Büngül büngül (Kar.) \\
\hline Avuç avuç (Çank.) & Üçer üçer (Kar.) \\
\hline Gonu gonşum (Çank.) & Güzel güzel (Kar.) \\
\hline Diz dize (Çank.) & Süslü püslü (Kar.) \\
\hline Geriden geriye (Çank.) & Lüle lüle (Kar.) \\
\hline Pāre pāre (Çank.) & Ġavga galebe (Kar.) \\
\hline Sallana serpini (Çank.) & Gaşşık gaşşık (Kar.) \\
\hline Biyas biyas (Çank.) & Basamak basamak (Kar.) \\
\hline Yorgun yorgun (Çank.) & İyi kötü (Kar.) \\
\hline Zorlıya zorlıya (Çank.) & Damla damla (Kar.) \\
\hline Çaha çaha (Çank.) & Aparladık toparladık (Kar.) \\
\hline Tarlayı tahımı (Çank.) & Efil efil (Kay.) \\
\hline
\end{tabular}




\begin{tabular}{|c|c|}
\hline Pallayı pallayı (Kay) & Usul usul (Krkk.) \\
\hline Hallayı hallayı (Kay) & Ciplah cıplah (Krkk.) \\
\hline Araya araya (Kay) & Arayı arayı (Krkk.) \\
\hline Tek tek (Kay) & Parça parça (Krkk.) \\
\hline Ayrı ayrı (Kay) & Yavaş yavaş (Krkk.) \\
\hline Sıhı sıhı (Kay) & Büyük guççük (Krkk.) \\
\hline Bükün bükün (Kay) & Üsdüm başım (Kırş.) \\
\hline Yangın yangin (Kay) & Zabah zabah (Kırş.) \\
\hline Temizlik memizlik (Kay.) & Vahıt vahit (Kırş.) \\
\hline Āladı māladıysa (Kay.) & Bahalı bahalı (Kırş.) \\
\hline Yavaş yavaş (Kay.) & Paslanı paslanı (Kırş.) \\
\hline Dolar dolar (Kay.) & Yan yan (Kırş.) \\
\hline Sorg்u süval (Kay.) & Nahış nahış (Kırş.) \\
\hline Çif çif (Kay.) & Düve düve (Kırş.) \\
\hline Parça parça (Kay.) & Zingir zingir (Kırş.) \\
\hline Saçıp savıp (Kay.) & Oynayı oynayı (Kırş.) \\
\hline Vuruşu vuruşu (Kay.) & İnil inil (Kırş.) \\
\hline Azar azar (Kay.) & Güççük güççük (Kırş.) \\
\hline Baş başa (Kay.) & Dört beş (Kırş.) \\
\hline Gopadıp gopadıp (Kay.) & Malın mülkün (Kırş.) \\
\hline Güreş müreş (Krkk.) & Yana yana (Kırş.) \\
\hline Tiha basa (Krkk.) & Gocayı gocayı (Kırş.) \\
\hline Tingir mingir (Krkk.) & Eşin dosdun (Kırş.) \\
\hline Tek tük (Krkk.) & Yavaş yavaş (Kırş.) \\
\hline Kömür mömür (Krkk.) & Gice gündüz (Kırş.) \\
\hline Çaha çaha (Krkk.) & Coşgun coşgun (Kırş.) \\
\hline Tohlu mohlu (Krkk.) & Bāmda bahçemde (Kırş \\
\hline Oylum oylum (Krkk.) & Sıra sıra (Kırş.) \\
\hline
\end{tabular}




\begin{tabular}{|c|c|}
\hline Üve üve (Kırş.) & böyle böyle (Nev.) \\
\hline Gara gara (Kırş.) & çoluh çocuh (Nev.) \\
\hline Yahş1 yahşı (Kırş.) & tüllü tüllü (Nev.) \\
\hline Çalalar çırıllar (Kırş.) & şaĥh şaĥ (Nev.) \\
\hline Sin $\sin ($ Kırş. $)$ & direşi direşi (Nev.) \\
\hline Yeke yek (Kırş.) & imekleyi imekleyi (Nev.) \\
\hline Gülüşü gülüşü (Kırş.) & didini didini (Nev.) \\
\hline Tel dal (Kırş.) & gup gup (Nev.) \\
\hline Dōrudan dōru (Kon.) & gonu gonşu (Nev.) \\
\hline Ohur ohumaz (Kon.) & gil gindap (Nev.) \\
\hline Halini hatırını (Kon.) & gonca gonca (Nev.) \\
\hline Gaya gaya (Kon.) & goyuh goyuh (Nev.) \\
\hline Sık1 sıkı (Kon.) & ameley mameley (Nev.) \\
\hline Birer birer (Kon.) & fırıl firıl (Nev.) \\
\hline Sarmaş dolaş (Kon.) & soluh soluĥ (Nev.) \\
\hline gucak gucā (Kon.) & gule gule (Nev.) \\
\hline cit cit (Nev.) & gonu gomşu (Nev.) \\
\hline tah tah (Nev.) & bağırır çağırır (Nev.) \\
\hline cib cib (Nev.) & gaynayı gaynayı (Nev.) \\
\hline şir şir (Nev.) & sürünü sürünü (Niğ.) \\
\hline aşşa yuharı (Nev.) & arada sırada (Niğ.) \\
\hline fırlanı fırlanı (Nev.) & sallana sallana (Niğ.) \\
\hline givrahlı donangılı (Nev.) & didek didek (Niğ.) \\
\hline yumşah yumşah (Nev.) & mahrim mahrim (Niğ.) \\
\hline döğüş çekiş (Nev.) & goşa goşa (Niğ.) \\
\hline şordan şurdan (Nev.) & daşdan daşa (Niğ.) \\
\hline gopuşu gopuşu (Nev.) & dere tepe (Niğ.) \\
\hline gapanı gapanı (Nev.) & gendi gendine (Ni⿱̆. ) \\
\hline
\end{tabular}




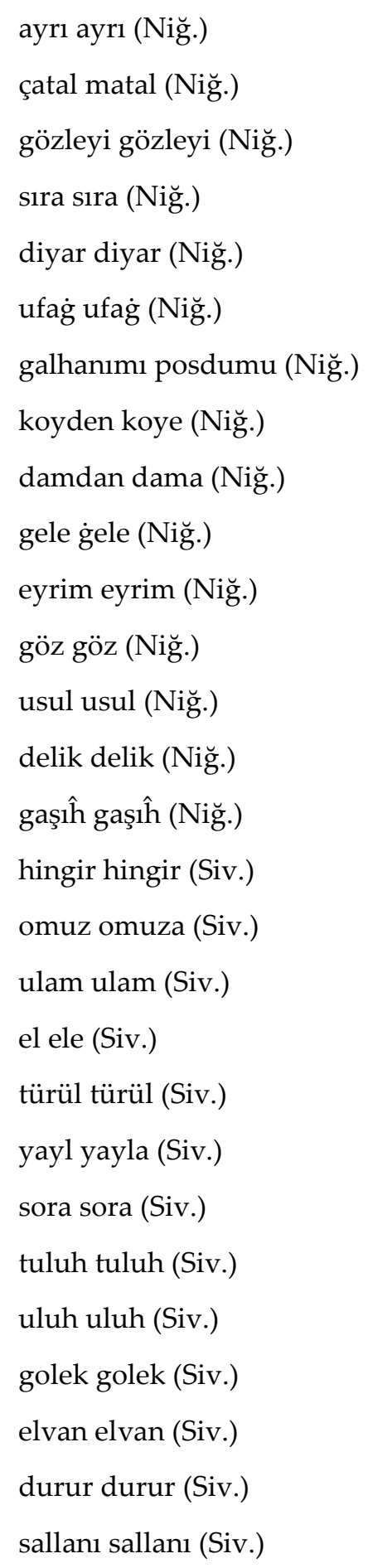

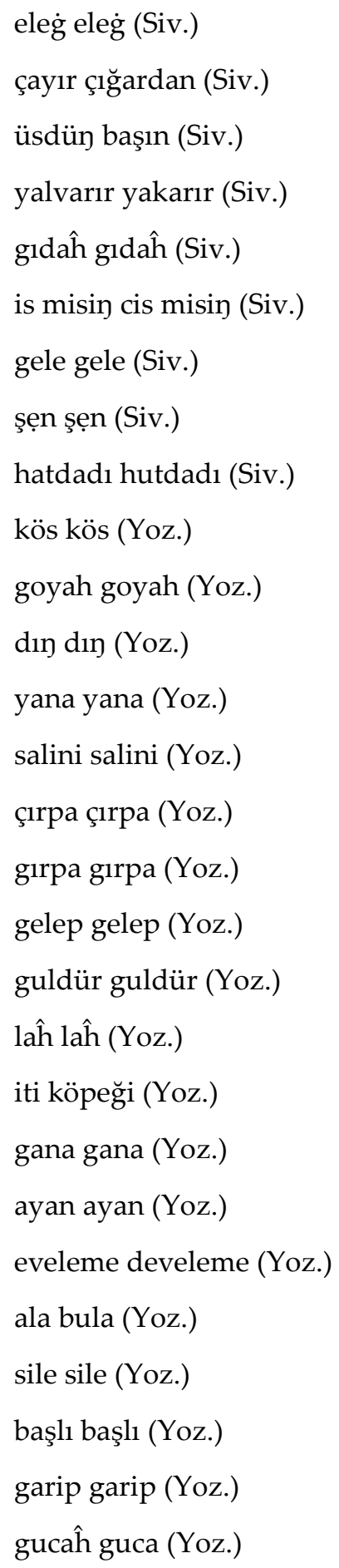




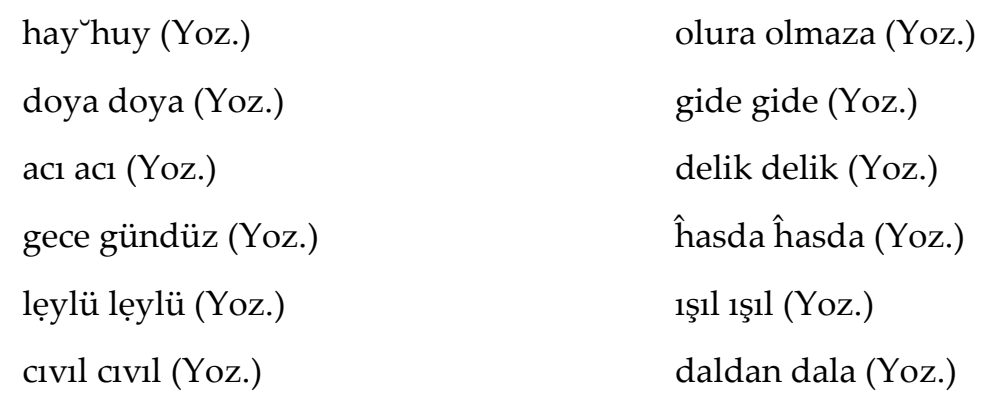

Bölgeye ait olan sıraladığımız ikilemeleri yapılışı ve sözcük türü olarak iki ana başlık altında değerlendireceğiz.

\section{Yapılışı Bakımından İkilemeler}

\subsection{Aynı Sözcügün Tekrarı ile Yapılan ikilemeler}

Aynı sözcüğün tekrarı ile kurulan ikilemelerdir. Bu şekilde yapılan ikilemeler pekiştirme ve anlamı güçlendirme görevindedir. İç Anadolu Bölgesi ağızlarında en fazla geçen ikileme türü bu şekilde yapilan ikilemelerdir.

Angaradan çıkdım yollar bükrüm bükrüm. (Ank.,Beyp.,133)

Bölük bölük dürdüler. (Esk.,AİAD,153)

Gelür saline saline. (Çank.,AAT.,92)

Işıl ışıl eder gurbetin daşı. (Yoz.,OAAD.,158)

Büyük kız evin yahşı yahşı. (Kır., Kır. Yör. Ağz.,225)

Gidince biz güççük güç̧̧ük beş çocuh galdıh. (Kır.,Kır. Yör. Ağz.,244)

\subsection{Eş anlamlı Sözcüklerin Tekrarı İle Yapılan İkilemeler}

Eş anlamlı iki sözcüğün birlikte kullanımıyla yapılan ikilemelerdir. Çalışmamızda bu şekilde yapılan ikilemelere örnekler geçmektedir fakat sayısı diğerlerine nazaran azdır.

Çana çolme gurtlu çobana varman. (Esk.,AİAD.,138)

Yimediğini saçıp savıp gediyor. (Kay.,OAAD.,45)

Sorgu sual yoh. (Kay.,OAAD.,56)

Bi gavga galebe olmasa çıkar gelir. (Kar.,Kar. Yör. Ağz.,171) 
O ikimillonu fakire fukareye daıdın. (Kar. Kar. Yör. Ağz.,161)

Meresiciye galır o malın mülkün. (Kır.,Kı.Yör. Ağz.,242)

\subsection{Zıt Anlamlı Sözcüklerin Tekrarı İle Yapılan İkilemeler}

Birbiriyle zıt anlamlı iki sözcügün yan yana kullanılmasıyla yapılan ikilemelerdir. Bu şekilde kurulan ikilemeler genellikle de açılklanmak istenen kavramın sınırlarını belirlemek için kullanılır ${ }^{32}$. Örneğin "Konuyu iyi kötü anladı." derken konunun iyi ile kötü arasında vasat durumda anlaşıldığı anlamı verilmektedir. Ağz.,171)

İyi kötü kendi kendilerine çerez gollar. (Kar., Kar. Yör.

Gelin büyük guççük, yaren yoldaş güye gınası yahalım. (Kırkk, OAAD.,215)

Aşşa yuharı altı bin verir. (Nev.,Nev. Yör. Ağz.,184)

Gice gündüz çalışırsın işine. (Kır.,Kır. Yör. Ağz.,238)

o adamın yanına varın öte bete alme. (Ank., Beyp. İlç. A $\breve{g} ., 108)$

\subsection{Yakın Anlamlı Sözcüklerin Tekrarı İle Yapılan İkilemeler}

Yakın anlamlı iki sözcüğün birlikte kullanımı ile yapılan ikilemelerdir. İkilemeyi kuran sözcüklerin anlam yönünden bir yakınlığı olduğu gibi ses yönünden de yakınlıkları söz konusudur. Örneğin yalan yanlış ikilemesi anlam ve ses yönüyle yakınlığı olan iki sözcükten meydana gelmiştir. İç Anadolu ağızlarında bu şekilde yapılan ikileme örnekleri fazla olmamakla birlikte tespit edilmiştir.

Öğlenneyin üsdüm başım yırtdırır. (Kır.,Kır.Yör.Ağz.,254)

Anamnan sarmaş dolaş oluruz. (Kon.,Ermnk Ağz.,12)

Patşa olanın halini hatırını sorduktan sonra: (Kon.,Ermnk. A $\breve{g} z ., 7)$

Döğ̈̈ş çekiş herkes hasim. (Nev., Nev. Yör. Ağz.,174)

Dere tepe düz gider. (Niğ.,OAAD.,22)

32 Vecihe Hatiboğlu, age, s.59 
Yalvarır yakarır tavuğa. (Siv., Siv. Tok. İl. Ağz.,78)

\subsection{Yansıma Sözcüklerle Yapılan İkilemeler}

İkilemeler içinde yansıma sözcüklerle kurulan ikilemeler önemli yer tutmaktadır. Çalışmamız olan İç Anadolu ağızlarında da çokça örneği bulunmaktadır. Konuyla ilgili temel kaynak olan Hamza Zülfikar'ın "Türkçe'de Ses Yansımaları" eserinde yansıma sözcüklerle kurulan ikilemeleri "tam ikileme" ve "kısmi ikileme" olarak ikiye ayırmıştır. Bu ayrımı yaparken de ses değişmesine uğramamış birbirinin aynı (tık tık, kütür kütür, cıvıl cıvıl vb.) iki yansıma sözcüğün kurduğu ikilemelere "tam ikileme", aralarında ses değişikliği bulunan iki yansıma sözcügün (pat küt, paldır küldür vb.) kurduğu yansıma ikilemelere ise "kısmi ikileme" demiştir. İnceleme alanımız İç Anadolu Bölgesi ağızlarında her iki şekilde de ikileme örnekleri bulunmaktadır.

Gannarın içinde böle inil inil gidiyollar. (Kır., Kır. Yör.Ağz.,244)

Def ellerinde zingir zingir zilliler. (Kır., Kır. Yör. Ağz.,247)

Şah şah gayniyacah. (Nev., Nev. Yör. Ağz.,119)

Firıl firıl fillandırıyo beni. (Nev., Nev. Yör. Ağz., 125)

Gannım gup gup ediyo. (Nev., Nev. Yör. Ağz.,135)

Bir pınara vardım şir şir ahıyor. (Nev.,OAAD.,77)

Cıvıl cıvıl öter Yozgatın guşu. (Yoz.,OAAD.,158)

\subsection{Biri anlamlı Diğeri Anlamsız İki Sözcügün Tekrarı İle Yapılan İkilemeler}

$\mathrm{Bu}$ tür ikilemelerde genellikle birinci unsur anlamlı ikinci unsur anlamsızdır. İkinci unsur tek başına anlamsız gibi olsa da ikileme kurulduğunda yanındaki anlamlı sözcükle birlikte bütün olarak bir anlam kazanır. Eski püskü ikilemesini örnek olarak değerlendirelim. Birinci unsur tek başına anlaml, ikinci unsur ise tek başına anlamsızdır. Birlikte ikileme kurduklarında ise birinci unsurun anlamını pekiştiren, güçlendiren bir anlam ortaya çıkmaktadır. Vecihe Hatiboğlu ikilemelerle ilgili kitabında bu tür ikilemelerde anlamsız olan sözcük için anlamlı sözcüğün gölgesi olduğunu ama anlamı pekiştirmeye yardımcı olduğunu söylemiştir. 
İç Anadolu Bölgesi ağızlarında bu şekilde yapılan ikilemeler tespit edilmiştir.

Çoluh çocuh hindiye gadar uraşdıh. (Nev., Nev. Yör. Ağz.,143)

Nedir goynundaki yamrı yumrular. (Esk., AİAD.,140) A $\breve{g} z ., 171)$

İşte bi gavga galebe olmasa çıkar gelir. (Kar., Kar. Yör.

Cumaat tek tük gelmeye başladılar. (Kırkk., Karakeçili A $\breve{g} ., 93)$

Gina gecesun de gonu gomşu ahrabaları gelir. (Nev., Nev. Yör. Ağz.,121)

\subsection{Her İkisi de Anlamsız İki Kelimenin Tekrarı İle Yapılan İkilemeler}

Tek başına anlamsız iki sözcüğün birlikte kullanımı ile kurulan ikilemelerdir. Sözcükler tek başına anlamsızdır fakat birlikte ikileme kurduklarında bir anlam kazanırlar. Örneğin ıvır zıvır ikilemesi bu yolla yapılmış bir ikilemedir. Sözcüklere tek tek bakıldığında anlamsızdır fakat birlikte kullanıldığında "gereksiz, önemsiz şey" anlamını kazanmaktadır. Yansımalarla kurulan ikilemeleri de aslında bu başlıkta değerlendirebiliriz; çünkü yansımaların kurduğu ikilemelerde yansıma olan kelime tek başına kullanıldığında anlamsızdır. Fakat biz değerlendirmemizde ayrıca bir yansıma ile kurulan ikilemeler tasnifi yapmayı daha uygun gördük. Taradığımız ağız bölgesinde bu şekilde kurulan ikilemeler vardır.

Aşğa didek didek çıhar benim tütünüm. (Niğ.,OAAD.,30)

Hatdadı hutdadı geşdi eşi. (siv., Siv. Tok. İl Ağz.,71)

Suya gidem uluh uluh. (Siv., Siv. Tok. İl. Ağz.,48)

Ulam ulam olmuş yatan yazılar. (Siv., Siv. Tok. İl. Ağz.,83)

Mal uşağı hingir hingir gülüyor. (Siv., Siv. Tok. İl. Ağz.,102)

Hay huy demiye dilim dolaşdı. (Yoz.,OAAD.,166) 
Şo gelen kös kös, bizim azıhcımola. (Yoz.,OAAD.,196) OAAD.,65)

Keyiyesi bükün bükün, gayalarda galdı dakın. (Kay.,

\subsection{Sözcüklerin Olumlu ve Olumsuz Şekillerinin Birlikte Kullanılması İle Yapılan İkilemeler}

$\mathrm{Bu}$ şekilde yapılan ikilemelerde genellikle fiillerin olumlu ve olumsuz şekilleri birlikte kullanılarak yapılır. Özellikle de zarf-fiil eki olan "-r..-mez" eki kullanılarak yapılır. Örneğin; "İçeri girer girmez onu gördüm." cümlesinde geçen ikileme bu türden bir ikilemedir. Anlamca birbirinin olumsuzu olan bu kelimeler birlikte kullanılarak söz konusu eyleme tezlik, çabukluk anlamı kazandırmıştır. Çalışmamızda bu türden ikilemeler bulunmaktadır.

Olura olmaza ben yar mi derim? (Yoz. OAAD.,159)

Pallaa pallamaz bi atlii garabakalı dutuyo. (Ank.,Beyp İlç. Ağz.,131)

Görü görmez baurmuş aya gakmış. (Ank., Beyp. İlç. Ağz.,130)

Ezanı ohur ohumaz atlının önüne eniyor. (Kon., Ermnk ağz.,4)

\subsection{Sayılarla kurulan ikilemeler}

Sayılarla kurulan ikilemeleri iki grupta değerlendirmek gerekir. Birinci grup iki rakam ya da sayının art arda kullanılmasıyla yapılan ikilemelerdir, ikincisi de rakam ya da sayılara üleştirme eki er/-ar eki getirilerek yapılan ikilemelerdir. "Konuyu iki üç seferde ancak anlayabildi." cümlesinde geçen iki üç ikilemesi bahsettiğimiz birinci gruba ait bir ikilemedir. "Çocuklara elmaları ikişer ikişer dağıttık." Cümlesinde geçen ikişer ikişer ikilemesi de ikinci grup diye bahsettiğimiz gruba dahil bir ikilemedir. Sayılarla yapılan ikilemeler de ikilemenin unsuru sayılar ardışık sayılar da (beş altı, bir iki vb.) olabilir, ardışık olmayan belli bir sisteme göre sıralanmayan rakamlardan da (üç beş, yimi beş oyuz vb.) kurulabilir.

Altına dört beş gişi girer merdivenin. (Kır., Kır. Yör. Ağz.,243)

Vadinizi birer birer yerine getircem. (Kon., Ermnk Ağz.,10)

Üçer üçer serdik mi bir ya eridiriz. (Kar., Kar. Yör. Ağz.,168) 


\subsection{Ses Değişmesine Uğrayarak Oluşan İkilemeler}

\subsection{1. İkinci Kelimenin Ön Sesi Tamamen Değişen İkilemeler}

$\mathrm{Bu}$ tür ikilemelerde ikinci kelime aslında ilk kelimenin tekrarıdır fakat aynı kelime ikinci kez söylenirken ilk sesi değiştirilerek söylenir. Çalışmamızda bu tür ikileme örnekleri bulunmaktadir. OAAD.,17)

Gozanda çatal matal, arasında aslan yatar. (Niğ.,

Su $\boldsymbol{m u}$ vedük bilmen napduk. (Ank., Beyp. İlç. Ağz.,123)

Ulladan çıkin mıkin deme demiş. (Ank., Beyp. İlç. Ağz.,122)

Düme müme bişe gomadı. (Ank., Beyp. İlç. Ağz.,121)

$\mathrm{Ne}$ ise çırpinduk mirpinduk bizim de Halit diye bi polisimiz varımış. . (Ank., Beyp. İlç. Ağz.,121)

Şinci yok düğün müğ̆̈̈n köde. (Ank., Beyp. İlç. Ağz.,116)

Yourdum va yeşil meşil çanakda. (Esk.,AİAD.,139)

Temizlik memizlik yapacah adamlar yapsın. (Kay., OAAD.,61)

Berberden geldi süslü püslü, kimse görmiyecek. (Kar., Kar. Yör. Ağz.,168)

\subsection{2. İkinci Kelimeye Ses İlavesi Yapılan İkilemeler}

Bu şekil kurulan ikilemelerde diğerinde olduğu sözcüklerde herhangi bir ses değişikliği yoktur. İkilemenin ilk unsurunun aslında tekrarı olan ikinci unsurun önüne bazı sesler eklenerek yapılır. Çalışma alanımız olan İç Anadolu ağızlarında bu tür örnekler bulunmakla beraber çok fazla değildir.

Ameley mameley ona ayet döt bin liriya yapıp virecek. (Nev., Nev. Yör. Ağz.,127)

Öle möle derken imkanı yok. (Ank., Beyp., İlç. Ağz.,123) 
Unu munu etdük faik başladı gülme. (Ank., Beyp., İlç. Ağz.,123)

Elemeden melemeden kendini sakın dolamadan. (Ank., Beyp., İlç. A ğz.,119)

Aladı maladıysa gız oglanı da kesdi. (Kay., OAAD.,59)

\section{Sözcük Türü Bakımından İkilemeler}

2.1. İsim görevinde Kullanılan İkilemeler

\subsubsection{Cins İsim Olarak Kullanılan İkilemeler}

Cümle içerisinde isim görevinde kullanılan ikilemelerin büyük bir kısmı cins isim türündedir.

(Esk.,AİAD.,140)

Nedir o goynundaki yamr yumrular.

(Çank.,AAT.,83)

Kose tarlayı tahımı satıp bir eşşeg almış.

Sorgu süval yoh. (Kay.,OAAD.,56)

Kır.Yör.A ̆̆z.,235)

Baamda bahçemde çalışıyorum. (Kır.,

Sin sin gurallar, ataş yahallar. (Kır.,Kır.Yör.Ağz.,222)

Tah tah ses gelirdi. (Nev., OAAD., 77) Kar. Yör. Ağz.,161)

O suyu bi böcü börtü düşmemesi için dökeler. (Kar.,

Ondan giri işte bi gavga galebe olmassa çıar gelir. (Kar., Kar. Yör. A ğz., 171)

OAAD.,61)

Temizlik memizlik yapacah adamlar yapsın. (Kay.,

\subsection{2. Özel İsim Olarak Kullanılan İkilemeler}

İç Anadolu Bölgesi ağızlarına ait metinlerde geçen ikilemelerin isim görevinde kullanıldığ 
görevinde kullanılan bu ikilemelerin sadece bir tanesi özel isimden oluşturulmuştur. İkilemenin birinci unsuru bir özel isimdir, ikinci unsur da bu özel isimden ses değişikliği yoluyla yapılmış yeni bir sözcüktür. İncelediğimiz metinler de bu şekilde kurulan sadece bir ikileme örneği tespit edilmiştir.

Beni de Nallıhanlı ala bütün tanır. Şu Bilal milal, fettan Bilal. (Ank., Beyp.,Illç.Ağz.,125)

\subsubsection{Hal Ekiyle Kurulan İkilemeler}

$\mathrm{Bu}$ şekilde yapılan ikilemelerde ikilemenin her iki unsuru genellikle aynı sözcüktür fakat bu kelimelere çeşitli hal ekleri getirilerek ikileme yapısı oluşturulmuştur. $\mathrm{Bu}$ tür ikilemelerin teşekkülünü şu şekillerde formüle edebiliriz: isim+isim+a/e, isim+a/e+isim, isim+den/dan+isim+a/e. Aşağıda sıraladığımız örneklerde de bunları görmek mümkündür. İç Anadolu ağızlarında bu şekilde yapılmış çokça ikileme örneği tespit edilmiştir.

Baş başa galıp da dökdüğümüz diller. (Kay.,OAAD.,

A $\breve{g} z ., 81)$

$$
\text { Ondan giri gol gola girerdin. (Kar., Kar. Yör. Ağz., }
$$

Yeke yek düşmana varmah sıramız. (Kır., OAAD.,

Gır atım da damdan dama eşinir. (Niğ, OAAD.,9)

Eşyalarım da koyden koye daşınır. (Niğ.,OAAD.,9)

Keklik atlar daşdan daşa. (Niğ., OAAD.,26)

El ele vermiş de geden gözeler. (Siv.,Siv. Tok.ìl

\subsection{Sıfat Görevinde Kullanılan İkilemeler}

İç Anadolu ağızlarından tespit ettiğimiz ikilemelerin cümle içerisinde sıfat görevinde kullanıldığı çok miktarda örnek bulunmaktadır. Bu örneklerin büyük bir kısmı niteleme sıfatı şeklinde olmakla birlikte çok azı da sayı sıfatı olarak kullanılmıştır.

Oklu yaylı olun olsun. (Esk., AİAD.,123) 
Yordum va yeşil meşil çanakda. (Esk.,AİAD.,139)

İşi gücü olan on beş yirmi arhadaş gezerdik. (Kar., Kar. Yör. A $\breve{g} ., 153)$

Altına dört beş gişi girer merdivenin. (Kır., Kır. Yör. Ağz.,243)

Cıplah cıplah dölleri var. (Kırkk,OAAD.,207)

Tohlu mohlu bir goç aldıh. (Kırkk.,Karakeçili Ağz.,9)

Gara gara gazannar, gara yazı yazannar. (Kır., Kır.,Yör. Ağz., 225)

Önüzde sıra sıra badeler de...(Kır.,Kır.Yör.Ağz.,233)

\subsection{Zarf Görevinde Kullanılan İkilemeler}

Metinlerden tespit ettiğimiz ikilemelerin cümle içinde büyük oranda zarf görevinde kullanılmıştır. Zarf görevinde kullanılan bu ikilemelerin de bir kısmı durum zarfı, bir kısmı da zaman zarfı olarak kullanılmıştır.

\subsubsection{Durum Zarfı Olarak Kullanılanlar}

Durum zarfı olarak kullanılan ikilemeler cümle içerisinde eylemin anlamını durum yönüyle belirtmişlerdir. Çalışma alanımız İç Anadolu Bölgesi ağızlarında çokça bu görevde ikileme örneği tespit edilmiştir. Cümlede durum zarfı görevinde kullanılan ikilemelerin oranı, zarf görevindeki ikilemeler içinde en fazla olanıdır.

Rüzgarlar eser gaba gaba. (Ank., Beyp,İlç.Ağz,134)

Ak sular akar harll harll. (Esk.,AİAD.,153)

Garagollar gol gol oldu yürüdü. (Esk.,AİAD.,151)

Gelür saline saline. (Çank., AAT.,92)

Helal olsa yassa goynuma girse deyelim helisa helisa. (Çank., AAT.,91)

A $\breve{g} z ., 162)$

Gayri suyu büngül büngül gaynadırız. (Kar., Kar. Yör.

Civür civür öter yaylanın guşu. (Çank.,AİAT.,124)

Yimedini saçıp savıp gediyor. (Kay.,OAAD.,45) 


\subsubsection{Zaman Zarfı Olarak Kullanılanlar}

Zaman zarfı olarak kullanılan ikilemeler cümle içerisinde eylemin anlamını zaman yönünden belirtmişlerdir.

Gece gündüz aşıkının dilinde. (Esk.,AİAD.,139)

Gice gündüz çalışırsın işine. (Kır.,Kır.Yör.Ağz.,238)

Efen seni vahıt vahıt yalardı. (Kır.,Kır.Yör.AğZ.,254)

254)

Zabah zabah acıh çızı dutdurur. (Kırş., Kır. Yör. Ağz.,

\subsubsection{Miktar Zarfı Olarak Kullanılanlar}

Eylemin anlamını miktar yönüyle belirten ikilemelerdir. Taradığımız metinlerde sadece bir örnekte miktar zarfı görevinde kullanılan ikileme bulunmaktadır.

Herkeş o sudan azar azar gapışır. (Kay.,OAAD.,48)

\subsection{Zamir Görevinde Kullanılan İkilemeler}

Zamir görevinde kullanılan ikileme örneği sadece birkaç örnekte tespit edilmiştir.

Şordan şurdan hediye gelip-batur. (Nev.,Nev.Yör.Ağz.,173)

\subsection{Fiil Görevinde Kullanılan İkilemeler}

Bölge ağızlarında tespit edilen ikilemelerden fiil türünde olanları elimizdeki örnekleri değerlendirerek iki gruba ayırdık. Tespit ettiğimiz fiil türündeki ikilemelerin bir kısmı kip ve şahıs eki alarak çekimli fiil olmuştur, bir kısmı da zarf-fiil eki alarak zarf-fiil olmuştur ve cümle içerisinde de zarf olarak kullanılmıştır.

\subsection{1. Çekimli Fiil Olarak Kullanılanlar}

Fiil görevinde kullanılan ikilemelerden çok azı çekimli fiil olarak kullanılmıştır.

(Esk.,AİAD.,141)

Goyun seni güddüm güddüm yetiştirdim.

Gider gider baçada yatar. (Esk., AİAD.,125)

Yisem yisem doymasam. (Çank.,AAT.,133)

Olura olmaza ben yar mi derim? (Yoz.,OAAD.,159) 
OAAD.,59)

aladı maladıysa da gız oglanı da kesdi. (Kay., Yör. Ağz.,176)

Biz gendimizi ıcık aparladık toparladık. (Kar., Kar. (Kır., Kır. Yör. Ağz., 222)

\subsubsection{Zarf-Fiil Olarak Kullanılanlar}

Fiil görevinde kullanılan ikilemelerin büyük kısmının zarf-fiil olarak kullanıldığ geçen ikilemer çoğunlukla -a/-e zarf-fiil ekini almıştır. Yöre ağızlarında bu ek bazı örneklerde -1/-i şekline de dönüşmüştür.

Gocayı gocayı yaşın yüz olur. (Kır., Kır. Yör. Ağz.,

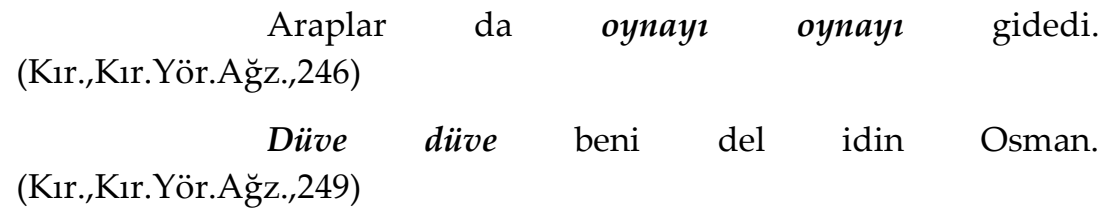

İki gişi didini didini çekerik. (Nev.,Nev.Yör.Ağz.,135)

(Nev.,Nev.Yör.Ağz.,136)

Nöğürecan, direşi direşi ocan batar.

Sallanı sallanı gide koğuşa. (Siv., Siv.Tok. İl Ağz.,21)

Sora sora vardım hacı köyüne. (Siv.,Siv.Tok.II

A $\breve{g} z ., 60)$

\section{Sonuç}

Çalışmamızda inceleme alanımız İç Anadolu bölgesine ait 13 ilden derlenen metinleri tarayarak 271 adet ikileme tespit ettik. İç Anadolu ağızlarında her bölgede görebileceğimiz ikileme örnekleri olmakla birlikte Türkiye Türkçesinde hiç karşılaşmadığımız ikileme örnekleri de karşımıza çıkmıştır. "büngül büngül, bükün bükün, böcü börtü, hingir hingir, golek golek" gibi ikilemeler buna örnektir. Türkiye Türkçesinde şu an kullanılmayan bu ikilemeler ses özellikleri yönünden Eski Türkçe ile ilgili de bağlantı kurmada bizlere yardımcı olabilir. 
Bölgenin 13 ilinden taradığımız metinlerden en az Aksaray en fazla Niğde ilinden ikileme örneği tespit edilmiştir. Bölgenin bu iki ili sınır hatta biri diğerinin eski ilçesi olmasına rağmen çalışmamızda böyle bir rakamsal farklılık ortaya çıktı. Bunda tabiî ki derleme yapılan kişinin dil özellikleri de etkili olmuş olabilir. Bölgeden derlenmiş metinler içinde nesir ve nazım türünde derlemeler bulunmaktaydı. Nazım türünde olan derlemelerde ikileme örneklerine daha sık rastlanmıştır.

İç Anadolu Bölgesi ağızlarında ikilemeleri yapılışlarına göre değerlendirdiğimizde en fazla aynı sözcüğün tekrarı ile yapılan ikilemeler karşımıza çıkmakta, en az da sözcügüün olumlu ve olumsuz halinin birlikte kullanımı ile yapılan ikilemeler karşımıza çıkmaktadır. İkilemeleri cümle içindeki görevlerine göre değerlendirdiğimizde de en fazla isim ve zarf görevinde, en az da zamir görevinde kullanıldığı görülmektedir. Zarf görevinde kullanılanların ise büyük kısmı durum zarfı görevinde kullanılmıştır, çok azı da zaman ve miktar zarfı olarak kullanılmıştır. Fiil görevinde kullanılan ikilemeler ise çekimli fiil ve zarf-fiil görevlerinde kullanılmıştır fakat bunlar içerisinde zarf-fiil görevinde kullanılanların sayısı daha fazladir.

Ağızlar şüphesiz ait olduğu dilin zengin birer hazineleridir. Dilin içerisinde o gün olmayan çok kelime ağızlarda varlığını devam ettirebilmektedir. Bu yüzden çok önemli kaynaklar olan ağız derlemeleri içerisinden tespitte bulunduğumuz ikileme örneklerinin de bu noktada bizlere fayda sağlayacağı düşüncesindeyim. Bu kaynaklarda tespit edilen ve yazı dilimizde bugün kullanılmayan sözcükler ve içerisinde zengin örnekleri bulunan ikilemeler, gerek anlamsal gerek fonetik açıdan değerlendirmelerde yol gösterecek çok değerli malzemelerdir. Ses uygunluğuna ve ses benzerliğine dayandığı için bir müzik esintisi ve ahenk sağlayan ikilemenin ${ }^{33}$ İç Anadolu ağızlarında da zengin örnekleriyle yaşamaktadır.

\section{Ağız Bölgesinde Yer Alan İllerin Kısaltmaları}

Aks.: Aksaray

Ank.: Ankara

Esk.: Eskişehir

\footnotetext{
${ }^{33}$ Vecihe Hatiboğlu, age, s.62
} 
Çank.: Çankırı

Kar.: Karaman

Kay.: Kayseri

Krkk.: Kırıkkale

Kırş.: Kırşehir

Kon.: Konya

Nev.: Nevşehir

Niğ.: Niğde

Siv.: Sivas

Yoz.: Yozgat

\section{Kaynaklar Ve Kaynak Kısaltmaları}

ALKAYA, Ercan, Orta ve Doğu Karadeniz Ağızlarında Görülen İkilemeler Üzerine Bir Değerlendirme, Turkish Studies, Volume 3 Issue 3, 2008, s. 37-76

BİLGEGİL, M. Kaya, Türkçe Dilbilgisi, Dergah Yayınları, 3.Baskı, İstanbul 1984.

CAFEROĞLU, Ahmet, (AAT), Anadolu Ağızlarından Toplamalar, TDK Yay., Ankara 1994

CAFEROĞLU, Ahmet, (AİAD), Anadolu İlleri Ağızlarından Derlemeler, TDK Yay., Ankara 1995

CAFEROĞLU, Ahmet, (OAAD), Orta Anadolu Ağızlarından Derlemeler, TDK Yay., Ankara 1995

CAFEROĞLU, Ahmet, (Siv.Tok.İl.Ağz.), Sivas ve Tokat İlleri Ağızları, TDK Yay., Ankara 1994

CAFEROĞLU, Ahmet, Konya İlinin Ermenek Ağzı,

(Kon.Ermnk.Ağz.), TDAYB., Ankara 1972

ÇAĞATAY, Saadet, Uygurcada Hendiadyoinler, Türk Lehçeleri Üzerine Denemeler, Ankara Ün. DTCF Yay., Ankara 1978, s. 29-66 
ERDEM, Mehmet Dursun, “Harezm Türkçesinde İkilemeler ve Yinelemeler Üzerine", Bilig, S. 33, Bahar 2005, s. 189-225

ERGIN, Muharrem, Türk Dil Bilgisi, Bayrak Yayınları, İstanbul 2012

GÜLENSOY, Tuncer, Türkçe El Kitabı, Akçağ Yayınları, 6. Baskı, Ankara 2010

GÜLENSOY, Tuncer; ALKAYA, Ercan, Türkiye Türkçesi Ağızları Bibliyografyası, Akçağ Yayınları, 3. Baskı, Ankara 2011

GÜNŞEN, Ahmet, (Kır.Yör.Ağz.), Kırşehir ve Yöresi Ağızları(İnceleme-Metin-Sözlük), TDK Yay., Ankara 2000

HATIPOĞLU, Vecihe, Türk Dilinde İkileme, TDK Yay., Ankara 1981

KARAAĞAÇ, Günay, Türkçenin Dil Bilgisi, Akçağ Yayınları, Ankara 2012

KARAHAN, Leyla, 1999. Türkçede Söz Dizimi, Akçağ Yayınları, Ankara, 2012

KORAŞ, Hikmet, Karaman ve Yöresi Ağızları (İnceleme-MetinlerSözlük), (Kar.Yör.Ağz.), Yüksek Lisan Tezi, Erciyes Üniversitesi, Kayseri 1992

KORKMAZ, Zeynep, (Nev.Yör.Ağz.), Nevşehir Yöresi Ağızları, TDK Yay., 1994

KORKMAZ, Zeynep, Gramer Terimleri Sözlüğ̈̈, TDK Yay., 4. Baskı Ankara 2010

SEV, Gülsel, Divanü Lûgat'it Türk'te İkilemeler, TD, S. 634, Ekim 2004, s. 497-510

Türkçe Sözlük, TDK Yay., Ankara 2005 